\title{
Capacity Mapping and Institutional Management Model of Village Owned Enterprises (BUMDes) in North Sumatra
}

\author{
Asima Yanty Siahaan ${ }^{1 *}$, Piki Darma Kristian Pardede ${ }^{2}$, Yonathan FP Hutapea ${ }^{3}$ \\ ${ }^{1}$ Ilmu Administrasi Publik, Universitas Sumatera Utara, Medan, Indonesia \\ ${ }^{2}$ Ilmu Pemerintahan, Universitas Darma Agung, Medan, Indonesia \\ ${ }^{3}$ Lembaga Studi dan Advokasi KebijakanMedan, Indonesia \\ Email: asimayantysiahaan@gmail.com
}

\begin{abstract}
This article aims at exploring the challenges of institutional management of BUMDes in North Sumatra and develops an effective BUMDes model management for creating independent professionals of rural economic institutions. It focuses on access, participation, and control on resource management and decision making of BUMDes. This study implied a qualitative approach as action research. Initial data collection techniques included in-deep interviews, case studies, focused group discussions, and observations. Further interventions were followed after initial findings and joint evaluation of BUMDes institutions. The research informants consisted of Community Empowerment Agencies, heads of the village, BUMDes institutions, NGOs, and local communities as beneficiaries in Dairi and Langkat regencies. The study reveals BUMDes in North Sumatra still lack of professionalism and sense of belonging in managing and developing rural community economic development. This is due to BUMDes in North Sumatra ignorance on institutional management in regulation, professional form of business, administration, reporting and accountability, capital, and assets, as well an impact to public and village. Furthermore, local authorities considered the existence of BUMDes as merely project oriented miniature for the villages which were yet to be based on data and actual need of villagers, thus, failed to contribute to the empowerment and welfare of the villages. This study suggests the urgency of increasing awareness, capacity, and institutional commitment of BUMDes to integrate organizations and improve collaboration between actors as the key to increase the achievement of BUMDes in running its business more effectively.
\end{abstract}

Keywords: Capacity Mapping, Institutional Management Model, Village-Owned Enterprises (bumdes).

\section{INTRODUCTION}

One of the mandates of Law no. 6 of 2014 concerning Villages is establishing the BUMDes institution (Village Owned Enterprises) as a village business that is used as a source of village income. The establishment of BUMDes is an effort to place this business entity as an important element in economic support and has social benefits. BUMDes is expected to have a vision and mission as a social entrepreneur to empower small and micro-scale enterprises (SMEs) and marginalized communities. BUMDes (Permendagri No 39/2010) is an economic institution that was born in conjunction with the Village Law. In contrast to cooperatives owned by a group of people, BUMDes, in this case, becomes the full right of all village communities. Many village-owned enterprise institutions have been established since the regulations related to BUMDes, which were then followed up through local government intervention with various village empowerment programs in each region and issued regional rules for establishing and managing villageowned enterprises.

According to the Center for Study on Dynamics of Development Systems Guidelines for the Establishment and Management of BUMDes (2007: 4-5), seven main characteristics distinguish BUMDes from commercial, economic institutions (cooperatives) in general, particularly BUMDes are owned by the village and managed together. The business capital comes from the town $(51 \%)$ and from the community, which is socialized by the Head of the Central Nusantara Village Empowerment Volunteer or PPRPDN (49\%) through equity participation (shares or shares). BUMDes operations are rooted in local culture (local wisdom) and are run based on the potential and results of market information. The benefits obtained by BUMDes aim to improve the welfare of members (capital) and the 
community through village policies. Then facilitated by the Government, Provincial Government, Regency Government, and Village Government as well as the Consultative Body (BPD), In its development through the Village Law, BUMDes has increasingly received a vital status and position as a legal entity that could manage the assets and socio-economic potential of the village. The operationalization of BUMDes management is strengthened through Permendes Number 4 of 2015 concerning the establishment, leadership and management, and dissolution of village-owned enterprises. In terms of regulations related to BUMDes institutions, ideally, it becomes a new hope and strengthens the economic springs of the village on a local scale.

Several studies conducted by village observers and academics related to Village-Owned Enterprises institutions in the research of the Village Renewal Development Forum and the Australian Community Development and civil society strengthening scheme (ACCESS) state that there are stereotyped views about BUMDes, which are government projects, such as with other projects that enter the village, so the legitimacy and attachment of BUMDes in the community are weak. However, not all BUMDes fail; some succeed well and have a substantial impact on improving the economy of rural communities. The success of BUMDes is due to the speed with which they transform from BUMDes, which are considered government projects, to become community owned BUMDes. This speed of transformation in many places is supported by village heads who are responsive, progressive, and encourage community initiatives. (Sukasmanto, 2014).

The Data from the Ministry of Villages for 2020 shows that the number of Village-Owned Enterprises (BUMDes) has increased. The focus of villages on improving themselves is strengthening the financial springs for village development, where since 2018, there have been 5,874 BUMDes, and in 2019 1,878 BUMDes were established. In fact, during the Covid-19 pandemic in 2020, 43 BUMDes could be found. Overall, there have been 51,134 BUMDes that Village Funds have channeled. Throughout 2015-2020 the Village Fund has been allocated as capital for Village-Owned Enterprises (Bumdes), the amount reaches Rp. 4.2 trillion. As a result, it was recorded that $\mathrm{Rp} 1.1$ trillion of Village Original Income was sourced from the profit-sharing of Bumdes. In North Sumatra in 2019, BUMDes income from MSME and tourism business units was able to gain original village income (Pades) of around Rp. 575.7 million, and an increase of Rp. 929 million in 2019. Until October 2020, Pades reached Rp. 1.4 billion and accounted for 68 percent of village finances.

The funds for the development of BUMDes are expected that BUMDes could become the economic locomotive of rural communities. So that the results of the BUMDes business can be beneficial for village development, village community empowerment, and assistance to the poor through grants, social service, and activities and are regulated in the Village Budget. BUMDes are managed in a spirit of kinship and cooperation and can run businesses in the economy and public services. In Permendes Number 4 of 2015 concerning BUMDes (Village Owned Enterprises), Article 6 allows villages to develop BUMDes together. Therefore, the societies already have BUMDes can work together at the sub-district level.

On the other hand, the number of newly born BUMDes indicates the number of funds invested by the government. When BUMDes fails, the village's ideals of self-reliance will be further out of reach-instead of leading to waste of state assets and financial inefficiency. Furthermore, it decreases village government institutions and creates new problems at the national level in Indonesia. Of course, the principles of BUMDes institutional management are essential to explain and harmonize the community's understanding and perceptions, including the village government, members (investors), the Village Supervisory Board, Regency Government, and the community. According to Ridlwan (2014), there are 6 principles in managing BUMDes institutions, namely: Cooperatives, all components involved in BUMDes should be able to work together to develop and maintain their business. Participatory, all components involved in BUMDes should be voluntarily willing or asked to provide support and contributions that could encourage the progress of BUMDes business. Emancipatory, all components involved in BUMDes should be treated equally, regardless of class, ethnicity, and religion. Transparent, all activities that can affect the public interest should be made efficiently and transparently so that the whole community can know them. Accountable, all business activities should be accountable technically and administratively, and Sustainable business activities should be developed and preserved by the community in the BUMDes environment.

Therefore, this study examines of BUMDes, in this case, by studying the determinants of BUMDes institutional performance. Based on pre-research and interviews with BUMDes actors or managers in North Sumatra, the most challenging thing for BUMDes to deal with is the management and financial administration of BUMDes. Therefore, based on the problems above, researchers are interested in researching and knowing "The Model of BUMDes Institutional Management in North Sumatra."

\section{RESEARCH METHOD}

The researcher uses a descriptive research method with a qualitative approach. The study was carried out on BUMDes located in Dairi Regency and Langkat 
Regency, North Sumatra, which have implemented the mandate of the Village Law by channeling Village Funds through Bumdes. Purposive sampling was used in determining the informants. Data collection techniques were carried out through in-depth interviews and Focused Group Discussions with various stakeholders in implementing the Village Fund policy in North Sumatra, discussions with informants, including Village Head, BPD, BUMDes Director, Treasurer, Head of Credit Union Unit, Village Facilitator (BUMDes Facilitator), farmer groups, community leaders and residents who use BUMDes funds. The secondary sources used were documents to support this research: journals, publications, books on villages and BUMDes, statutory regulations, and annual BUMDes accountability reports. The researchers would find the data through the field observation field. In this study, there were four main agendas that needed to be carried out to optimize the role of BUMDes, mainly: Institutional Development and Strengthening; this stage includes the formulation of regulations/regulations and organizational structuring. Capacity building, including empowerment, training, and mentoring in settings. The government does this to the regional government, and the provincial government does it to the village government and BUMDes; Strengthening Market Management. It includes partners in cooperating with third parties, expanding markets, and facilitating access to various resources; Sustainability, including organizing, advocacy forums, and promotions.

\section{RESEARCH FINDINGS AND DISCUSSIONS}

\subsection{Analysis of BUMDes Institutional Management}

Institutions are dynamic, whose existence in a community is constantly changing, adapting to changes in the community. Oliver Williamson (2000; 535) analyzes the institutional change in four levels, namely institutional changes that occur at, social level, the level of formal institutions environment, the level of governance, and changes are continuous.

Institutional capacity examines how the institutional capacity to achieve its own goals. This ability is measured from five aspects: strategic leadership, program planning management, and management and execution; allocation of owned resources and relations with external parties, namely to clients, partners, government policymakers, and external donors. Fourth, institutional performance. Three main things should be considered: the institution's effectiveness in achieving its goals, the efficient use of resources, and the institution's sustainability in interacting with outside interest groups.

\subsubsection{Local Resource Development}

The typological condition of the village in Dairi Regency is dominated by coffee and rice plantations, only a small part of which uses corn. This condition opens up opportunities for BUMDes together to make independent preparations as a unit of BUMDes. Opportunity to take advantage of the existing nature This condition is an advantage for BUMDes. If it is managed properly and can take advantage of current opportunities, it can accelerate the development of the BUMDes business unit. The capacity of the BUMDes Director in several villages in managing BUMDes management is, on average, quite capable, especially the chairman of BUMDes Baja Dairi, in Bangun Village in managing BUMDes administration where the Village Head and Head of BUMDes Baja Dairi have enough experience in managing business units to adopt their experience in BUMDes so that BUMDes Baja Dairi can become one of the pilot projects of the Ministry of Villages, PDT and Transmigration (Kemendesa).

However, it is still found in several villages that strengthening BUMDes business units has not become a priority because the capacity of actors is still relatively low. BUMDes administrators, village heads, and their apparatus do not yet understand the management and administration processes that should be mastered, so assistance is needed until the management is truly capable of managing BUMDes properly. With help carried out, it is hoped that the output of the training can be achieved. The success and failure of BUMDes are undoubtedly influenced by the leadership style of the village head, who can intervene with other village officials to be creative and innovate in the development of BUMDes. According to Likert in Thoha (2006:60), leaders can succeed if they have a participative management style. This style explains that leaders will grow if they are subordinate-oriented and based on communication. In addition, all parties in the organization, both subordinates, and leaders, apply supportive relationships to encourage associates to take responsibility for making decisions and implementing these decisions together.

\subsubsection{Financial Capital and Business Unit Activity Development}

Equitable participation from the Village Government puts BUMDes together to develop business units. Capital is very influential on the fast or slow development of BUMDes. The business unit development aspect is intended to see the result of BUMDes capital by comparing changes in current capital with initial capital. This capital development is expected to be able to become a driving force for business units managed by BUMDes. Based on the Head of Community Empowerment at the Dairi Dispemdes, from 161 villages, there are still around 25 villages from 13 sub-districts that have formed BUMDes. Sumbul Subdistrict has Pegagan 
Julu VII Village, with a Drinking Water Business Unit (established in 2017). Other villages with a drinking water business unit are Bonkaras Village (established in 2017) and Bakal Gajah Village (established in 2018). Both are located in the Silima Pungga-pungga subdistrict. In Parbuluan District, there is Bangun I Village; the BUMDes has three business units engaged in drinking water, credit union unit, and party equipment (established in 2017) and Bangun Village with BUMDes engaged in the Clean Water Business, Industrial Homes and Savings and Loans (formed in 2018). Meanwhile, in the Siempat Nempu Hulu sub-district, there are only Central Kuta Village, Pandiangan Village (Lae Parira), Berampu Village (Berampu), Lau Bangot Village (Tiga Lingga), and Jambur Indonesia Village (Siempat Nempu Hilir), all of which are engaged in the drinking water business and the village of Palding Jaya Sumbul (Three Lingga), Sosor Lontung Village and Sinampang Village (Siempat Nempu) is engaged in the Clean Water business unit.

However, in Sidikalang Subdistrict, only Kalang Simbara Village has a BUMDes with a Volleyball Field Facility business, and Party Building Rental formed with Village Regulation No. 3 of 2017. Gunung Tua Village (Tanah Pinem), the BUMDes manages Dodol and processed fried onions. While BUMDes manages the Savings and Loans Unit, namely Siboras Village (Silima Pungga-pungga), Simartugan Village (Pegagan Hilir), Silalahi II Village (Silahisabungan) and Sopobutar Village (Siemnempu Hilir). BUMDes operate the electricity payment service unit in Maju Village and Juma Teguh Village (Siempat Nempu).

Thus, there are in the sub-districts of Gunung Sitember and Sitinjo villages that do not yet have a BUMDes. Especially in Silalahi II Village, BUMDes will be engaged in the tourism sector by encouraging Tourism Villages according to the Ministry of Villages (Kemendes) direction to receive assistance if they attract 10,000 tourists every year. However, the service of BUMDes capital in Dairi and Langkat Regencies has not been maximized due to several factors. BUMDes have not yet a business plan, and management maximized due to a lack of knowledge and skills. There is no concern from the BUMDes management and the Government towards the culture of the community that program funds are contributions, so there is no obligation to return or report so that BUMDes capital is still deposited in the account. Furthermore, the use of the budget that is not following its designation, namely for infrastructure development or other forms outside the provisions of the rules for managing BUMDes.

\subsection{3 . BUMDes Institutional Capacity}

Institutional BUMDes in Dairi Regency have been established with a total of 72 BUMDes. The amount is quite large when compared to the area of the district. The characteristics of all BUMDes show similarities. The similarity of institutional aspects of BUMDes was established in Dairi Regency, where the year of establishment is almost the same, namely between 2017 2018 , and the most dominant establishment of BUMDes is 2017. The initial capital of BUMDes is between RP $15,000,000-\mathrm{Rp} 20,000,000$, - and there is no increase in business assets. The business classification carried out by BUMDes is serving and renting. Empirical facts explain that the business classification of BUMDes in Dairi Regency, which consists of doing and leasing, is a reinforcement that there is no basic assumption that is a reinforcement for a BUMDes institution, namely: good institutional governance and human resources for managing it. Theoretically and empirically, there are six business classifications, namely, serving, renting, banking, brokering, trading, and holding. The business classification explains the level of institutional quality of a BUMDes. It means that a BUMDes that manages a business at the Trading level will have better governance and human resources than a BUMDes that works a serving type of business.

Institutional BUMDes in Dairi Regency have been established with a total of 72 BUMDes. The amount is quite large when compared to the area of the district. The characteristics of all BUMDes show similarities. The similarity of institutional aspects of BUMDes was established in Dairi Regency, where the year of establishment is almost the same, namely between 2017 2018, and the most dominant establishment of BUMDes is 2017. The initial capital of BUMDes is between RP $15,000,000-R p 20,000,000$, - and there is no increase in business assets.

The business classification carried out by BUMDes is serving and renting. Empirical facts explain that the business classification of BUMDes in Dairi Regency, which consists of doing and leasing, is a reinforcement that there is no basic assumption that is a reinforcement for a BUMDes institution, namely: good institutional governance and human resources for managing it. Theoretically and empirically, there are six business classifications, namely, serving, renting, banking, brokering, trading, and holding. The business classification explains the level of institutional quality of a BUMDes. It means that a BUMDes that manages a business at the Trading level will have better governance and human resources than a BUMDes that works a serving type of business. 
Table 1. Institutional Aspect : Organizational Structure of BUMDes Management Organization

\begin{tabular}{lllccc}
\hline Distric & \multicolumn{1}{c}{ Village } & \multicolumn{1}{c}{ BUMDes } & Advisor & Implementing Advisor & Controller \\
Dairi & Bangun 1 & Baja Dairi & Active & Active & Active \\
& Pegagan Julu & Pegagan Julu & Quite Active & Quite Active & Quite Active \\
& Gunung Sitember & Sitember & Nothing & Nothing & Nothing \\
& Pandiangan & Lae Parira & Active & Active & Active \\
& Sitinjo & Sitinjo & Nothing & Nothing & Nothing \\
& Silalahi II & Silahisabungan & Quite Active & Quite Active & Quite Active \\
& Batu Jonjong & Sumber Rejeki & Less Active & Less Active & Less Active \\
& Timbang Lawan & Angkasa & Active & Active & Active \\
& Sei Musam & Sei Musam & Nothing & Nothing & Nothing \\
& Namo SIalang & Salang Jaya & Quite Active & Quite Active & Quite Active \\
& Sei Serdang & Serdang Karya & Less Active & Less Active & Less Active
\end{tabular}

Source: (the data processed from researcher 2020)

In the table above, we can see that the management of BUMDes in Langkat shows that currently, only the names of BUMDes exist. The organizational structure of BUMDes management no longer exists. Two other BUMDes can be identified as quite active, namely Sumber Rezeki BUMDes and Salang Jaya BUMDes. Meanwhile, BUMDes Serdang Karya was identified as less active management. While in Sidikalang Regency, it shows that only BUMDes in Bangun, Pandiangan, Silalahi, and Pegagan Julu villages are pretty busy running BUMDes businesses dominated by drinking water businesses.

The factor causing the failure of these programs is the lack of creativity and innovation of rural communities in managing economic activities in rural areas. The economic, institutional systems and mechanisms in rural areas are not running effectively, so that it has implications for the failure of the programs that have been implemented. The strategy of strengthening the village economy through BUMDes is one solution to release the dependence of rural communities on government assistance.

\subsection{Factors Affecting the Management and Development of BUMDes}

\subsubsection{The Strengthening of BUMDes Institutional}

Based on the Focus Group Discussion results, we could focus on strengthening the BUMDes institutional on three main things. Namely first, mapping village assets, secondly increasing management and management capacity, and maintaining the network between BUMDes. First, the mapping of village assets is one of the substantive things carried out to strengthen BUMDes institutions.

In mapping village assets, it can be seen what products or services are superior to the village, besides what skills and capacities are possessed by community

members that can be utilized and developed and community social values that could mobilize to encourage social change. From mapping the village assets, an inventory empowerment design was made, which aims to strengthen BUMDes.

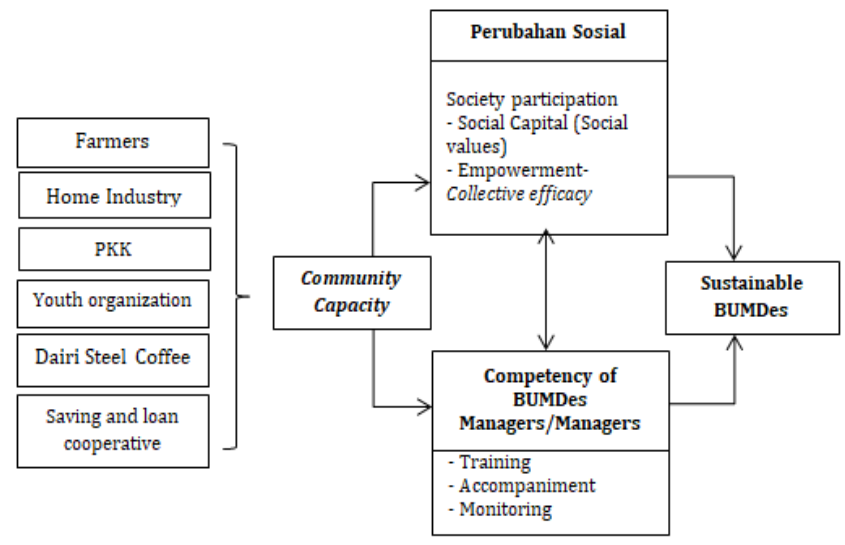

Figure 1. BUMDes Strengthening Framework (Source: Village FGD analysis in Bangun Village, District. Dairi and Langkat).

The strengthening focus from the framework could be done by increasing the capacity of BUMDes management and management. The mapping of village assets and suggestions for improving the management and management capacity of BUMDes can be started by collaborating with private institutions and village youth who join the youth group. Collaboration could be done, for example, related to training in agricultural product processing and effective marketing. It is relatively easier to train youths than to train formal BUMDes administrators who are not young anymore. Youth groups also have more energy and more creative ideas to market superior village products to parties outside the village. The utilization of trading methods through electronic media can also be used as the first step to market select village products. The focus of strengthening could be done by increasing human resources, strengthening the relationship between BUMDes and MSMEs, and Allocation of Government Funds. 


\subsubsection{Human Resources}

The human resources capacity of BUMDes managers is based on excerpts from interviews with informants. Researchers can analyze that human resources are supporting factors in developing BUMNDes productivity management, including experienced BUMDes directors, village heads, and assistants, from 23 Bumdes; around $60 \%$ can manage the administration of BUMDes where the Village Head and BUMDes head in Bangun Village, Gajah Village, Sosor Lontung Village, Sinampang Village, Gunung Tua Village, Kalang Simbara Village have enough experience in managing business units so that they can adapt their expertise in BUMDes. So that BUMDes in the village can become one of the pilot projects of the Ministry of Villages, PDT and Transmigration (Kemendesa). On the other hand, the limited capacity development for BUMDes Operational Implementers from the Village and District in the southeast is the problem of limited capacity. It is also very possible because the mapping of the needs of BUMDes, which is quite a lot in Dairi and Langkat Regencies, has not been carried out comprehensively. In general, the education for implementing BUMDes is high school. On average, interviews conducted with BUMDes Management show that the BUMDes Board of Directors is based on people who want to do and work. It is because BUMDes have not been able to professionally hire people, in addition to the limited human resources in the village. The following can be seen in the capacity development that has been received by BUMDes, among others:

Table 2. BUMDes Human Resource Capacity Development

\begin{tabular}{lll} 
Distric & \multicolumn{1}{c}{ Village } & \multicolumn{1}{c}{ BUMDe } \\
Dairi & Baja Dairi \\
& & \\
& & \\
& & \\
& Pegagan Julu & \\
Gunung Sitember & Pegagan Julu \\
Pandiangan & Sitember \\
& Lae Parira \\
& Sitinjo & \\
Silalahi II & Sitinjo \\
Batu Jonjong & Silahisabungan \\
Timbang Lawan & Sumber Rejeki \\
& Angkasa \\
Langkat & Sei Musam & Sei Musam \\
& Namo Sialang & Salang Jaya \\
& Sei Serdang & Serdang Karya
\end{tabular}

Source: (the data processed from researcher 2020)

The majority of BUMDes administrators feel that the Dairi and Langkat District governments' capacity development is minimal. They think that to become a
BUMDes that can serve the village community and compete with other parties. It must also have good human resource capacity.

Institutional strengthening of BUMDes needs to be encouraged from the readiness of resources according to the actors' objectives, characters, indicators, and capacity. What is essential is the legality that ensures optimization of BUMDes productivity. One important thing in the management of BUMDes is that in managing BUMDes, transparent governance and reporting are needed for the government and the community. It means that the primary management must be completely transparent and open so that there is a check and balance mechanism by both the village government and the community. For the next step, it is vital to prepare business development plans

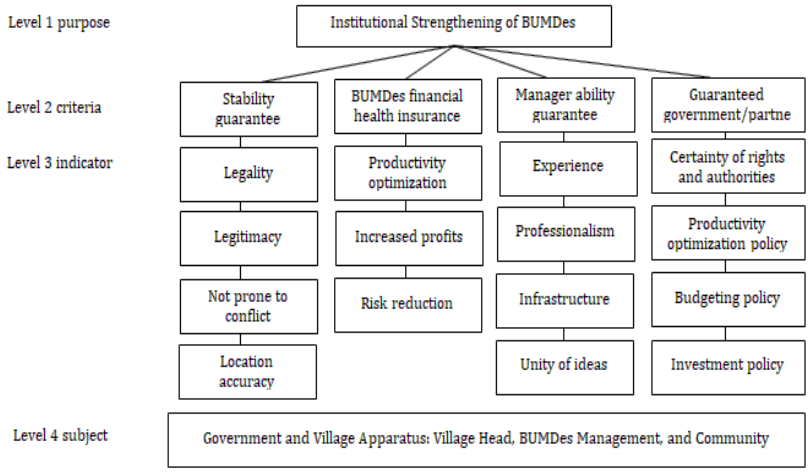

Figure 2. Institutional Strengthening of BUMDes (author,2021)

Judging from the picture above, the level of achievement of this BUMDes goal positions the Village

\author{
1. Administration Training \\ 2. Technical guidance for BUMDes management, Branding, \\ Processing and Training \\ 3. Training Product marketing \\ 4. Financial Reporting Training, and \\ 5. BUMDes Regulation Training \\ Administration Training, Technical guidance for BUMDes management \\ Technical guidance for BUMDes management \\ Administration Training, Technical guidance for BUMDes \\ management \\ Technical guidance for BUMDes management (BIMTEK) \\ Technical guidance for BUMDes management (BIMTEK) \\ Administration Training and BUMDes Regulation Training \\ Product Branding, Financial Reporting Training and BUMDes \\ Regulation Training \\ 2015, BIMTEK establishment of BUMDes \\ 2018, Financial management training \\ 2018, Financial management training
}

Government to be at a moderate level of achievement (performance interval 25-50\%). Indicators that need to be appropriately implemented are BUMDes working 
areas as per Mendesa Regulation No. 4 of 2015. Indicators that have not been met include village support in planning, working relationships (partnerships) institutional business unit programs, convergence and diversification of BUMDes programs, mobilization of funds, utilization of human resources potential, competitive grants for village development, as well as the establishment, structuring, and strengthening of BUMDes institutions.

In addition, indicators that need to be implemented but are not optimal are the socialization of the BUMDes program, the formation of the BUMDes Working Group Team, the mobilization of funds, and the utilization of personnel. The low performance of the establishment of BUMDes working areas is caused by the weak understanding of stakeholders about the concept of BUMDes, the subordinate role of stakeholders in planning the formation of work areas, and the ineffectiveness of relations between stakeholders in the implementation of coordination and cooperation in fulfilling the criteria and indicators for the construction of business units. To overcome the problem of the weak understanding and role in fulfilling these criteria and hands, it is necessary to empower stakeholders based on the level of interest and influence of stakeholders in fulfilling the criteria and indicators for developing BUMDes. It mapped the results of the stakeholder analysis assessment based on the level of importance and level of influence.

\subsubsection{The Relationship between Bumdes and the Development of Micro Enterprises and Village Self-reliance Based on Local Potential}

Based on primary data collected by researchers, the significance of BUMDes groups of business actors and significant professions in the Dairi district, the average sample is almost $50 \%$, showing consistency. It means that the occupations of the majority of the sample villagers have access to the professions they are involved Meanwhile, $25 \%$ of the target. In comparison, $25 \%$ still cannot be accessed with adequate information, so researchers have not included it in this analysis segment.

Alignment between the availability of professions involved by the community and the participation of BUMDes to form the business unit is the right first step. Because based on the percentage of the population in each village, it is known that the average number of lowincome families in the sample villages is $20 \%-35 \%$. At the same time, the rest are families with Prosperous II and III status. it means that BUMDes has had a share close to the need for access for the poor in the local area. However, suppose it is seen from the majority of the poor, $70 \%-80 \%$ work as farm labourers. In that case, the existing agriculture and fisheries segment has not facilitated the majority of low-income families in the Sample village. The misalignment between micro- enterprises and the choice of elements from BUMDes will directly impact slowing down residents' independence in the town, and $50 \%$ percentage is due to two factors: First, there is a misunderstanding between the concepts absorbed by the Villages of BUMDes actors. The BUMDes guide explicitly states that the establishment of BUMDes is based on the needs and potential of the village to improve community welfare. BUMDes is a pillar of economic activity in the town that functions as a social and commercial institution. BUMDes as a social institution sided with the community's interests by contributing to the provision of social services. Meanwhile, as a commercial institution, it aims to profit by offering local resources (goods and services) to the market.

\subsubsection{Government Fund Allocation}

The beginning of the BUMNDes policy was an initiation from the local government, who saw that the natural resources owned by each village area could be the primary driver in building village welfare. Through the PDTT of the Ministry of Villages, the government has set four priorities for using village funds in 2018, namely the development of superior products in rural areas, the effect of BUMDes, rembung and sports facilities. But there was a lot that the village could do with its funds apart from the four cases above.

Permendagri Number 39 of 2010 and Permendesa Number 4 of 2015 supervisors from the management organization only carry it out. The local government only plays a role in guiding BUMDes. In terms of capital, these two rules already regulate money and allow for capital from third parties, either in the form of grants or business cooperation with third parties. Regarding institutions, this study concludes that BUMDes should be able to form a business unit in the state of a Limited Liability Company as a capital partnership, developed based on an agreement, and carry out business activities with capital that BUMDes mostly own, following the laws and regulations regarding Limited Liability Companies; and Microfinance Institutions with a share of BUMDes of 60 (sixty) per cent, by the laws and regulations concerning microfinance institutions (Article 8 Permendesa Number 4 of 2015). Efforts to establish this legal entity will be beneficial for access to capital from third parties. In addition, legal entities will have consequences for managing financial separation and managing BUMDes and supporting the expansion of employment opportunities for rural communities.

\subsection{Community participation in the development of BUMDes in Dairi District}

The results of research related to the development of BUMDes institutions in Dairi Regency can be seen that 
the role of community participation in the development of BUMDes is divided into three stages, namely the planning stage, the implementation stage, and the maintenance stage. At the planning stage of the Joint BUMDes development, community participation is needed to explore ideas at the village level (musdes). This discussion activity is carried out to absorb the aspirations of the village community regarding the activities that will carried out in the upcoming BUMDes program.

The form of community participation provided at the planning stage is attendance at meetings and activeness in providing suggestions or proposals. At the program implementation stage, community participation can be seen from participation, including taking advantage of existing BUMDes business units such as savings and loans. The level of community participation in the maintenance phase consists of the contribution of labour and money. The form of community participation can be (a) community participation in the form of labour, such as community willingness to participate in community service activities (b) community participation in the form of assets, such as community willingness to make financial contributions to activities (c) community participation in the form of ideas, which are indicated by community participation in participating in village consultative forums.

However, there are weaknesses in the first level of community participation; the ability to diversify BUMDes business units is minimal because of the tendency for each village to imitate other villages in determining business units. Finally, the types and forms of business units tend to be homogeneous, such as drinking water businesses. Of these 25 BUMDes, there is still a lack of creativity and innovation in the form of products produced by BUMDes. The wealth of land, forests and available agrarian resources is still not seen as a resource that allows the development of BUMDes business innovation. So, this business has not been able to compete with similar BUMDes in the sub-district area. Likewise, there is a view that residents should not pay in full because the village business unit, according to the community, should be free.

\subsection{Constraints in Bumdes Institutions}

In this study, it was found that the weakness of BUMDes is because generally, BUMDes businesses do not have a business plan. This occurs more in the capacity of human resources who have not been able to provide these documents. So that the identification of needs and BEP projections (break event point) and possible losses that arise cannot be predicted. The results of the FGD also showed that participatory processes in the formation of BUMDes were often missed because the target orientation encouraged BUMDes with capital participation from the Village.
The findings also show that BUMDes equity participation is not by existing regulations (for example, the Company Law). it happened because the BUMDes were promised from the beginning of the village capital, so the capital did not match the needs. Still, the BUMDes did the planning according to the budget allocation provided by the village. Because it has not been managed optimally, BUMDes has not provided significant benefits to the village in the form of dividends for the local village PAD.

According to Yunanto (2003:2), there are five weaknesses in the current development of BUMDes, namely the inadequate arrangement of village institutions. As a result, BUMDes have not been fully institutionalized into the village government and economy. Furthermore, the village has limited human resources to manage and develop BUMDes accountable and perform well. So, initiatives from the local level to mobilize economic potential are still low, especially for improving villagers' social and economic welfare. Then the inefficient consolidation and cooperation process between stakeholders recognize BUMDes as an economic institution that plays a role in improving the people's economy. Moreover, the responsiveness of the Regional Government is frail in seeing BUMDes as a particular program to empower villages and community welfare.

Furthermore, the savings and loan business carried out by BUMDes in the Dairi district is generally not productive because it is oriented to providing loans without any savings from members. In addition, the return scheme is also carried out at the end of the year. The financial capacity of BUMDes managers still needs to be improved. In conclusion, the performance of BUMDes is only oriented to quantity targets. Finally, the establishment of BUMDes is more about fulfilling the programmatic requirements for establishing BUMDes.

Regarding management activities at BUMDes in Dairi and Langkat districts, it shows that currently, only the names of BUMDes exist, but in fact, the organizational structure of the BUMDes management organization no longer exists. Three other BUMDes can be identified as quite active, namely Baja Dairi BUMDes, Gunung Tua BUMDes and Gajah Mandiri BUMDes. Meanwhile, other BUMDes in Langkat Regency were identified as less active management

\section{CONCLUSION}

The institutional development of BUMDes in Dairi and Langkat Regencies for two years since its establishment has still not found its identity as the locomotive of the village economy. It is necessary to reform management so that BUMDes can survive. Among BUMDes that carry out development in terms of Local Resources, namely utilizing village communities 
who are members of the Bumdes to be involved in developing BUMDes in the future and encouraging the dissemination of regulations related to BUMDes, taking a Participatory Rural Appraisal (PRA) approach in mapping village potential and formulating priorities BUMDes efforts, and strengthening the organization and assistance of rural communities for economic development. The capacity and experience of BUMDes managers is undoubtedly an important asset in developing BUMDes. In addition, assets that are not functioning correctly in the village can have economic value if used properly. And governance in the management structure or BUMDes management starts from the ability to manage and comply with duties and functions, including fees for services trained in stages. In the process of collecting and developing BUMDes, various influential factors emerge, both supporting and hindering.

The supporting factor for the development of BUMDes is the extraordinary potential of BUMDes HR management in developing BUMDes in the future. Meanwhile, the inhibiting factor can be seen from the empirical facts that in North Sumatra, many BUMDes seem to be careless in choosing the type of BUMDes business without looking at prospects. It is not uncommon for BUMDes to miss several things in determining their business. It is inseparable from the process of establishing BUMDes, which seems only to fill the void in the mandate of the Village Law No. 6/2014 and the Minister of Village Regulation No. 4/2015.

In terms of village policies, consistency is needed in encouraging BUMDes institutional regulations. Ensuring that AD/ART, Village Regulations and Management Decrees are available is necessary so that the processes for organizing BUMDes can be carried out and have clear guidelines.

\section{REFERENCES}

[1] A Teori of Access, Rural Sociology, Vol. 68, No. 2, June 2003, 153-181, Jesse C. Ribot dan Nancy Lee Peluso

[2] Agus Adhari dan Ismaidar, 2017, Analisis Hukum Pembentukan Badan Usaha Milik Desa dalam Upaya Meningkatkan Pendapatan Asli Desa di Kecamatan Babalan Kabupaten Langkat, Dialogia Iuridica, Volume 9 Nomor 1, November 2017, p.013-028 Faculty of Law, Maranatha Christian University

[3] Amalia AD \& Syawie M (2015) The development of rural resilience with empowering concept: A study of sociological perspective. Sosio Informa 1 (2):175-188.

[4] Anggraeni MRRS (2016) Peranan Badan Usaha Milik Desa (BUMDes) pada kesejahteraan masyarakat pedesaan studi pada BUMDes di Gunung Kidul, Yogyakarta. Modus 28 (2):155

[5] AKATIGA (2000), the Center for Micro and Small Enterprise Dynamic (CEMSED), dan the Center for Economic and Social Studies (CESS).

[6] Atterton, J. 2001. The Role of Civil Society and Business Community in Rural Restructuring.Arkleton Centre of Rural Development Research. University of Abardeen. Scotland.

[7] Badan Penelitian dan Pengembangan Provinsi Sumatera Utara.2008. Kajian Peluang Bisnis Bagi Sepuluh Komoditi Unggulan di Sumatera Utara. Medan.

[8] Buku Panduan Pendirian dan Pengelolaan Badan Usaha Milik Desa (Bumdes), Pusat Kajian Dinamika Sistem Pembangunan, Fakultas Ekonomi, Universitas Brawijaya.

[9] EdyYusuf Agunggunanto, dkk "Pengembangan Desa Mandiri Melalui Pengelolaan Badan Usaha Milik Desa(Bumdes)" dalam Jurnal Dinamika Ekonomi Bisnis, volume 13 Nomor 1 Maret Tahun 2016, UNISNU Jepara

[10] O. E. Williamson, The New Institutional Economics: Taking Stock,(Looking Ahead. Journal of Economic Literature, 2000.), vol. 38, hlm. 595613.

[11] Suryanto, R. (2018). Peta Jalan Bumdes Sukses (Pertama). Yogyakarta: PT. Syncore Indonesia

[12] Putra, A. S. 2015. Badan Usaha Milik Desa: Spirit Usaha Kolektif Desa. Jakarta: Kementerian Desa, Pembangunan Daerah Tertinggal, Dan Transmigrasi Republik Indonesia

[13] Workshop Kebijakaan Optimalisasi Penggunaan Dana Desa di Desa Bangun, Babupaten Sidikalang, 24 September 2020.

[14] Workshop Kebijakaan Pemanfaatan Hasil Hutan Bukan Kayu di TNGL, Kabupaten Langkat, ELSAKA, 07 November 2020.

[15] Zubaidah, N. (2017). Dana Desa Stimulasi Pembentukan BUMDes. Sindonews. Retrieved from https://ekbis.sindonews.com/read/ 1221704/34/dana-desa-stimulasipembentukanbumdes- 1500366680 